\title{
Comparative Leaching Study on Conichalcite and Chalcopyrite Under Different Leaching Systems
}

\author{
Jiajia Wu, Junmo Ahn, and Jaeheon Lee* \\ Department of Mining and Geological Engineering, The University of Arizona, Tucson, AZ, 85721, USA
}

\begin{abstract}
Copper leaching from low-grade copper ore samples obtained from two active mines in the US, named conichalcite (sample A) and chalcopyrite (sample B), were studied under different leaching conditions using sulfuric acid and methane sulfonic acid (MSA). The conichalcite, sample A, is calcium-copper arsenite hydroxide $\left[\mathrm{CaCu}\left(\mathrm{AsO}_{4}\right)(\mathrm{OH})\right]$ with small amount of gold and other metals. The copper grade is $0.41 \%$ with $0.48 \%$ arsenic and $2.04 \%$ sulfur. The chalcopyrite, sample B, was the main mineral with $0.60 \%$ copper grade with $0.73 \%$ sulfur and $0.032 \%$ molybdenum. Leaching systems utilized two oxidants (ferric ion and hydrogen peroxide) to investigate the kinetics of copper extractions. All leaching tests were performed by bottle roll leaching tests with $6.25 \%$ pulp density for 24 hours. Results showed that the leaching kinetics were relatively fast for oxidized sample A. Overall copper recovery was slightly affected by the oxidants and higher than $60 \%$ copper extraction was observed. Screen fractioned materials and the leached residue analysis showed that the copper grade in the residues are relatively consistent with $0.14-0.16 \%$ copper. This results showed that the ore samples contains readily leachable copper and refractory elements in all size fractions. The refractory portion seems to be relative uniform with wide range of easily leachable copper with 0.30 to $0.54 \%$. Copper extraction from sample B using acids with ferric ion as an oxidant showed around $35 \%$ but it significantly increased over $80 \%$ using hydrogen peroxide as an oxidant. The copper extraction gradually increased up to $3.0 \mathrm{~mol} / \mathrm{L}$ hydrogen peroxide content.
\end{abstract}

(Received December 6, 2018; Accepted January 31, 2019)

Keywords: conichalcite, chalcopyrite, leaching, hydrogen peroxide

\section{INTRODUCTION}

In 2015, the copper recovered by leaching accounts for $43 \%$ of total copper production in the US [1]. The hydrometallurgical process for copper recovery is well developed over the years because it produces less waste than pyrometallurgy and presents great advantage in treating lowgrade materials.

Conichalcite with ideal formula $\mathrm{CaCu}\left(\mathrm{AsO}_{4}\right)(\mathrm{OH})$ is not well known. Generally, it is recognized as a secondary mineral in the oxidized zone of copper deposits, typically an alteration product of enargite. The leaching behavior of conichalcite is not fully clarified, and it is classified as refractory material under some occasions [2]. Chalcopyrite,

\footnotetext{
- Jiajia Wu, Junmo Ahn: Ph. D. Student, Jaeheon Lee: Professor *Corresponding Author: Jaeheon Lee [Tel: +1-520-488-0853, E-mail: jaeheon@email.arizona.edu] Copyright (c) The Korean Institute of Metals and Materials
}

one of the primary sulfide minerals, is very difficult to leach in acidic solution at ambient temperature. Many efforts have made to develop new methods to extract copper from chalcopyrite, such as utilizing bacteria or stronger oxidant $[3,4]$.

The conichalcite-rich deposit where sample A was received is located at the Maggie Creek district in Nevada's Carlin trend, USA. It is a subhorizontal, sedimentary rockhosted gold and copper deposit. Although it is productive for gold, there is large quantities of copper ores $(150 \mathrm{Mt}$, at an average grade of $0.25 \% \mathrm{Cu}$ ) [5,6]. In the supergene zone, conichalcite, chrysocolla, cuprite, native $\mathrm{Cu}$, chalcocite, malachite, and $\mathrm{Cu}$-bearing kaolinite, montmorillonite, and halloysite contribute to the composition of copper ore [7].

Sample B is originated from a chalcopyrite-rich deposit, located in southern Arizona, USA. It contains one of the largest supergene porphyry copper deposits in the world [8]. Both sulfide and oxide ores occur in the ore body and the 
Table 1. Chemical analysis of sample A. (\%)

\begin{tabular}{cccccccc}
\hline $\mathrm{Cu}$ & $\mathrm{Fe}$ & $\mathrm{As}$ & $\mathrm{S}$ & $\mathrm{Al}$ & $\mathrm{K}$ & $\mathrm{Mg}$ \\
\hline 0.41 & 5.36 & 0.48 & 2.04 & 7.04 & 3.03 & 0.31 \\
\hline $\mathrm{Ti}$ & $\mathrm{Ca}$ & $\mathrm{Ba}$ & $\mathrm{P}$ & $\mathrm{Cr}$ & $\mathrm{Pb}$ & $\mathrm{Ni}$ \\
\hline 0.26 & 0.28 & 0.21 & 0.16 & 0.06 & 0.04 & 0.02 \\
\hline
\end{tabular}

Table 2. Rock-forming minerals of sample A. (\%)

\begin{tabular}{cccccccc}
\hline Quartz & Muscovite & Alunite & Jarosite & Anhydrite & Magnetite & Hematite & Goethite \\
\hline 45.5 & 30.7 & 12.4 & 3.5 & 0.8 & 2.5 & 2.5 & 2.1 \\
\hline
\end{tabular}

main sulfide minerals are pyrite, chalcocite, and chalcopyrite. The predominant oxide minerals are chrysocolla and malachite. According to Enders's study [9], in the hypogene zone, copper content in the host rocks is fairly uniform $(0.39 \% \mathrm{Cu})$ but shows significant variations by rock-type. Chalcopyrite averages $0.56 \%$ and ranges from 0.025 to over $2.9 \%$, and correlates directly with the distribution of hypogene copper grade.

In this study, two samples are studied for copper extraction under various leaching systems consisted of different acids and oxidants. Sulfuric acid $\left(\mathrm{H}_{2} \mathrm{SO}_{4}\right)$ is a common lixiviant for copper leaching; methanesulfonic acid $\left(\mathrm{CH}_{3} \mathrm{SO}_{3} \mathrm{H}, \mathrm{MSA}\right)$ is widely used for rust and scale removers and electrodeposition $[10,11]$. Recently, more projects are focused on its application in the leaching process [12-14]. Hydrogen peroxide is adopted as an alternative oxidant to ferric ion. The specific goal of the research is to provide a comprehensive study of conichalcite dissolution and compare the leaching behavior of two copper minerals.

\section{MATERIALS AND EXPERIMENTAL METHOD}

\subsection{Materials}

As-received samples were crushed, ground and dry screened to obtain size fraction of $100 \%$ passing $2.00 \mathrm{~mm}$ and $0.075 \mathrm{~mm}$, respectively. Properly sized samples were rotaryspilt into $20 \mathrm{~g}$ test charges. Chemical analysis of sample A, assayed by ICP-OES following acid digestion, showed the copper content of $0.41 \%$ as listed in Table 1 . The mineral compositions were analyzed by QEMSCAN (Quantitative Evaluation of Mineralogy by Scanning Electron Microscopy), and the results are presented in Table 2 and Table 3 . In the ore sample, the main rock-forming minerals were quartz and muscovite. Conichalcite was the dominant copper-bearing mineral and pyrite was the second one with $20.83 \%$. Chrysocolla and malachite contain less than $5 \%$ of copper.

The chemical assay of sample $B$ is shown in Table 4 showing copper grade of $0.601 \%$. Chalcopyrite was the main copper-bearing mineral as $1 \%$ of chalcopyrite was seen in the XRD analysis result in Table 5. Since the sample was taken from the hypogene zone, it can be deduced that the copper minerals were mainly copper sulfides. All the percentages $(\%)$ in this paper are weight percentage $(\mathrm{wt} \%)$.

Table 3. Copper distribution in different minerals of sample A

\begin{tabular}{ccc}
\hline Copper-bearing mineral & Content $/ \%$ & Ratio/\% \\
\hline Conichalcite & 1.36 & 70.83 \\
Pyrite & 0.4 & 20.83 \\
Chrysocolla & 0.07 & 3.66 \\
$\mathrm{Cu}$ in micas and clays & 0.04 & 2.08 \\
Other Cu & 0.03 & 1.56 \\
Malachite & 0.02 & 1.04 \\
\hline
\end{tabular}

Table 4. Chemical analysis of sample B. (\%)

\begin{tabular}{ccccccc}
\hline $\mathrm{Al}$ & $\mathrm{K}$ & $\mathrm{Fe}$ & $\mathrm{S}$ & $\mathrm{Cu}$ & $\mathrm{Na}$ & $\mathrm{Mg}$ \\
\hline 5.75 & 3.79 & 0.94 & 0.73 & 0.601 & 0.42 & 0.13 \\
\hline $\mathrm{Ba}$ & $\mathrm{Ti}$ & $\mathrm{Ca}$ & $\mathrm{Mo}$ & $\mathrm{Zn}$ & $\mathrm{Pb}$ & $\mathrm{Zr}$ \\
\hline 0.09 & 0.04 & $<0.04$ & 0.032 & $<0.01$ & 0.0007 & 0.023
\end{tabular}

Table 5. XRD analysis of sample B. (\%)

\begin{tabular}{ccccccccc}
\hline Chalcopyrite & Pyrite & Quartz & K-Feldspar & Muscovite Group & Kaolinite & Plagioclase & Biotite Group \\
\hline 1 & 1 & 37 & 35 & 9 & 6 & 11 & 1 \\
\hline
\end{tabular}



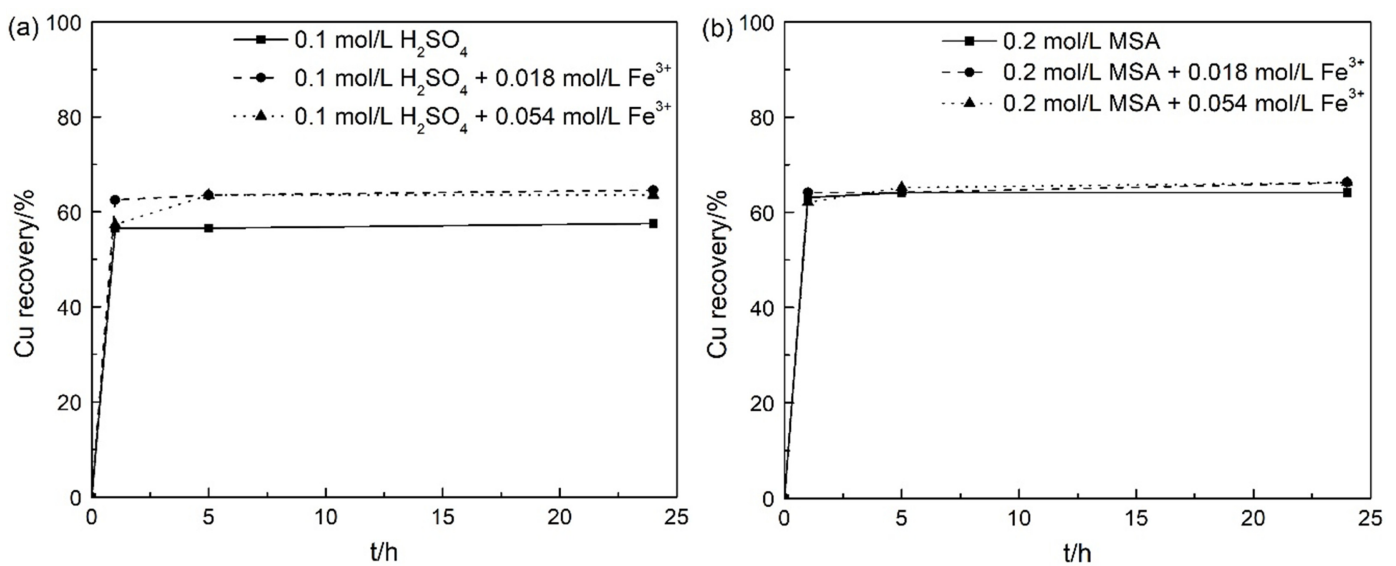

Fig. 1. Copper recovery of sample A under ferric leaching system with different lixiviants: sulfuric acid; (b) MSA
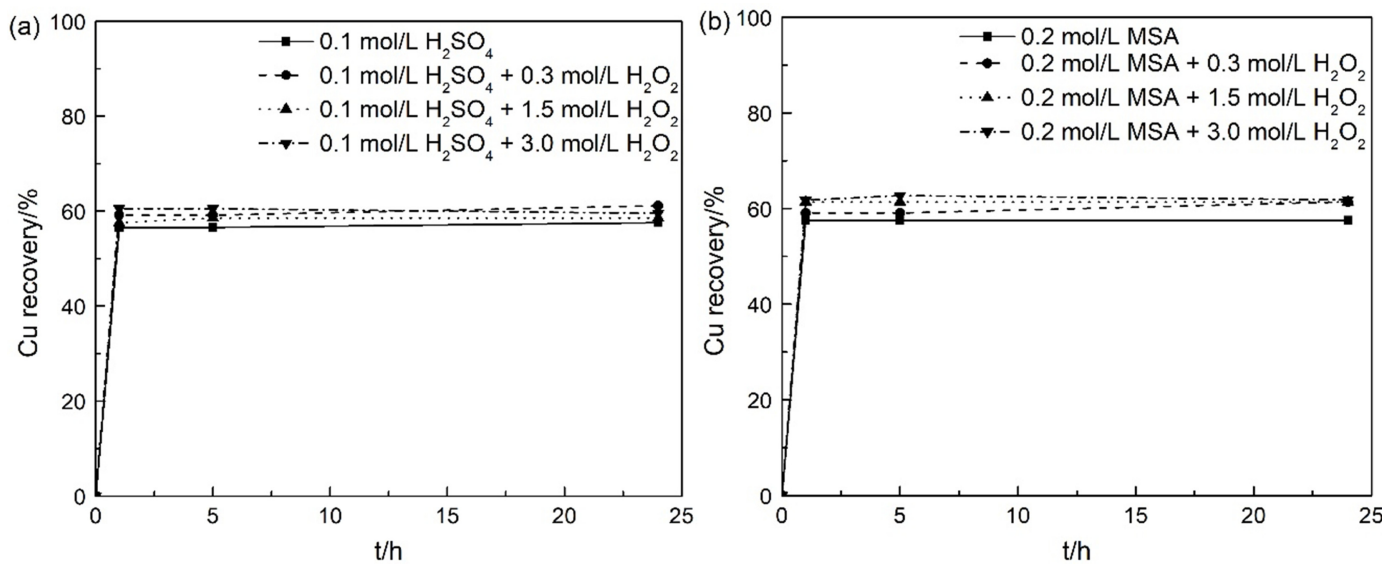

Fig. 2. Copper recovery of sample $\mathrm{A}$ under $\mathrm{H}_{2} \mathrm{O}_{2}$ leaching system with different lixiviants: (a) sulfuric acid; (b) MSA

\subsection{Experimental method}

Leaching tests were carried out by bottle roll tests. The pulp density of the leach test was $6.25 \%$ with $20 \mathrm{~g}$ solid and $300 \mathrm{~mL}$ solution. The bottle roll test was run for 24 hours at ambient temperature and pressure with uncapped bottle. Kinetic sample of $5 \mathrm{~mL}$ solutions were taken at 1, 6 and 24 hours using a syringe-membrane filter (pore size $0.45 \mu \mathrm{m}$ ) and analyzed by AAS (Atomic Absorption Spectrophotometer) for copper assay. Solution lost by sampling was compensated by addition of deionized water. The total leached copper was calculated by the initial solution volume before taking kinetic samples. In addition, concentration change of lixiviants was negligible by adding deionized water to compensate the volume. Sulfuric acid and MSA are used as lixiviants and ferric ion (added as $\mathrm{Fe}_{2}\left(\mathrm{SO}_{4}\right)_{3} \cdot 5 \mathrm{H}_{2} \mathrm{O}$ ) and hydrogen peroxide $\left(\mathrm{H}_{2} \mathrm{O}_{2}\right)$ are used as oxidants.

\section{RESULTS AND DISCUSSION}

\subsection{Conichalcite leaching test}

Copper recovery of sample A in sulfuric acid/MSA with ferric ion is shown in Fig. 1. The copper dissolution kinetics were relatively fast and reached the maximum value in five hours. Around $57 \%$ and $63 \%$ copper were extracted in $0.1 \mathrm{~mol} / \mathrm{L}$ sulfuric acid and $0.2 \mathrm{~mol} / \mathrm{L}$ MSA solution. Copper recovery increased by $7 \%$ after adding $0.018 \mathrm{~mol} / \mathrm{L}$ ferric ion into the sulfuric acid solution and no further increase was observed with $0.054 \mathrm{~mol} / \mathrm{L}$ ferric ion. However, the copper recovery was not significantly affected by ferric ion when MSA is used as lixiviant. The highest copper extractions about $64 \%$ were observed in both conditions.

Dissolution of sample A in $\mathrm{H}_{2} \mathrm{O}_{2}$ system is shown in Fig. 
2. The copper recoveries increased slightly even after 3.0 $\mathrm{mol} / \mathrm{L} \mathrm{H}_{2} \mathrm{O}_{2}$ addition, indicating the copper minerals in the sample A did not show the enhanced leaching behavior by hydrogen peroxide.

Barton et al. [2] reported that the QEMSCAN results indicated that conichalcite in the sample A was dissolved after leaching in both conditions. The remaining copperbearing minerals were copper coexisted with pyrite and copper minerals under detection limit of QEMSCAN, and they are not oxidized by ferric ion or $\mathrm{H}_{2} \mathrm{O}_{2}$ in this test. The dissolution of conichalcite in acid solution can be expressed as Equation (1).

$$
\mathrm{CaCu}\left(\mathrm{AsO}_{4}\right)(\mathrm{OH})+4 \mathrm{H}^{+} \rightarrow \mathrm{Ca}^{2+}+\mathrm{Cu}^{2+}+\mathrm{H}_{3} \mathrm{AsO}_{4}+\mathrm{H}_{2} \mathrm{O}
$$

To further study the leaching characteristics of conichalcite, $-2.00 \mathrm{~mm}$ samples were sieved to 4 different size fractions as shown in Table 6 . The four samples were then leached by $0.1 \mathrm{~mol} / \mathrm{L}$ sulfuric acid and $0.018 \mathrm{~mol} / \mathrm{L}$ ferric ion following the same procedure. The $\mathrm{Cu}$ contents in the heads and residues were analyzed by ICP-OES after acid

Table 6. Copper assay of sample A before and after leaching

\begin{tabular}{ccc}
\hline Size $/ \mathrm{mm}$ & Head $/ \%$ & Residue $/ \%$ \\
\hline$+0.85-2.00$ & 0.46 & 0.14 \\
$+0.15-0.85$ & 0.54 & 0.15 \\
$+0.075-0.15$ & 0.33 & 0.14 \\
-0.075 & 0.30 & 0.16 \\
\hline
\end{tabular}

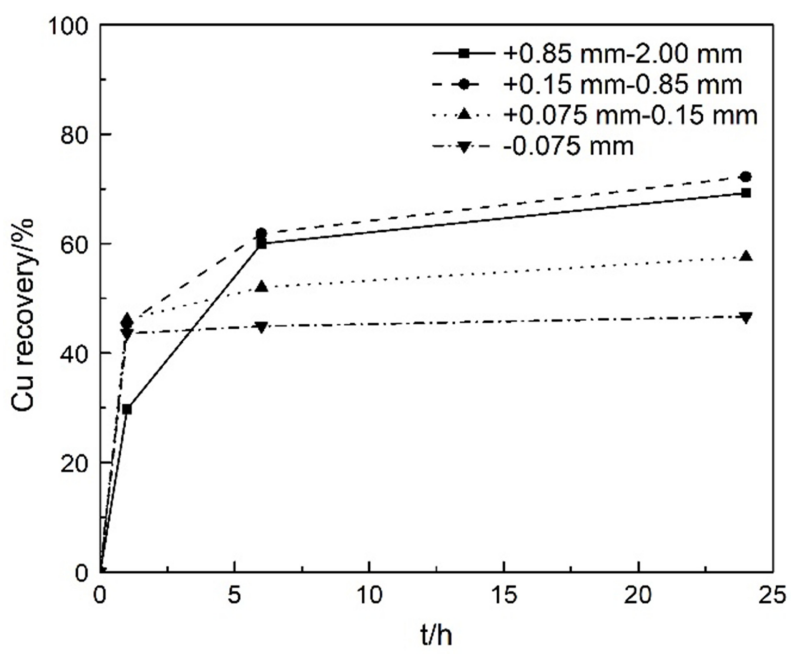

Fig. 3. Copper recovery from different size fractions of sample A. leaching conditions: $0.01 \mathrm{~mol} / \mathrm{L} \mathrm{H}_{2} \mathrm{SO}_{4}, 0.018 \mathrm{~mol} / \mathrm{L} \mathrm{Fe}^{3+}$ digestion, and leaching results are shown in Fig. 3.

The copper grade in the coarse particles $(>0.15 \mathrm{~mm})$ was higher than the finer portion, and higher copper recoveries were obtained. The leaching kinetics of $0.85 \mathrm{~mm}-2.00 \mathrm{~mm}$ particles was slowest because the copper is not fully liberated, and it took time for the lixiviant to diffuse through cracks and fractures of the particle. After leaching tests, the four residues showed similar copper grade, suggesting that the readily dissolved copper were extracted under the leaching condition and the copper sulfide was difficult to be dissolved. Further studies about mineral compositions of the four fractions will be run by QEMSCAN.

\subsection{Chalcopyrite leaching test}

Unlike sample A, chalcopyrite is reluctant to be dissolved in acidic solution. High temperature and oxidant are required to effectively leach copper from chalcopyrite.

Copper extraction with ferric as an oxidant shows lower than $20 \%$ as exhibited in Fig. 4 . In both leaching systems (sulfuric acid/MSA with ferric ion), the copper recoveries increased with the presence of $0.018 \mathrm{~mol} / \mathrm{L}$ ferric ion. However, further increase of copper extraction was not observed at higher ferric ion concentration. The highest copper recovery can be achieved was $35 \%$.

According to the mineral analysis from Section 2.2, copper existed as chalcopyrite accounts for approximately $50 \%$, and the remaining may be copper oxides or sulfides. From Fig. 4, copper extractions were less than $20 \%$ in sulfuric acid and MSA solution without oxidant in 24 hours, indicating the copper oxides, or easily soluble copper minerals, probably account for around $20 \%$ of the total copper minerals. The copper recovery increased after ferric ion addition can contribute to the dissolution of some secondary sulfide minerals and chalcopyrite. Theoretically, the reaction between chalcopyrite and ferric ion can be illustrated as Equations (2)-(3) [15].

$$
\begin{aligned}
& \mathrm{CuFeS}_{2}+4 \mathrm{Fe}^{3+} \rightarrow \mathrm{Cu}^{2+}+5 \mathrm{Fe}^{2+}+2 \mathrm{~S}^{0} \\
& \mathrm{CuFeS}_{2}+4 \mathrm{Fe}^{3+}+3 \mathrm{O}_{2}+2 \mathrm{H}_{2} \mathrm{O} \rightarrow \mathrm{Cu}^{2+}+5 \mathrm{Fe}^{2+}+2 \mathrm{H}_{2} \mathrm{SO}_{4}
\end{aligned}
$$

Under the conditions used, the reaction (3) is not likely happened [16]. The elemental sulfur $S^{0}$ will not be oxidized 

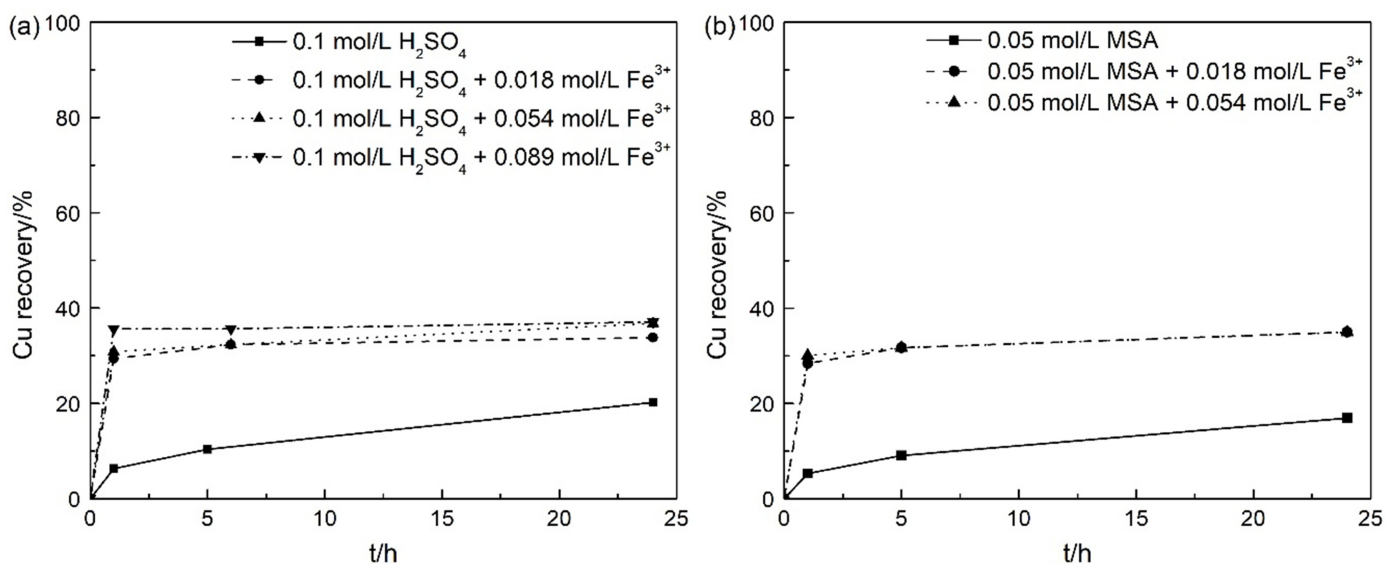

Fig. 4. Copper recovery of sample B under ferric leaching system with different lixiviants: sulfuric acid; (b) MSA
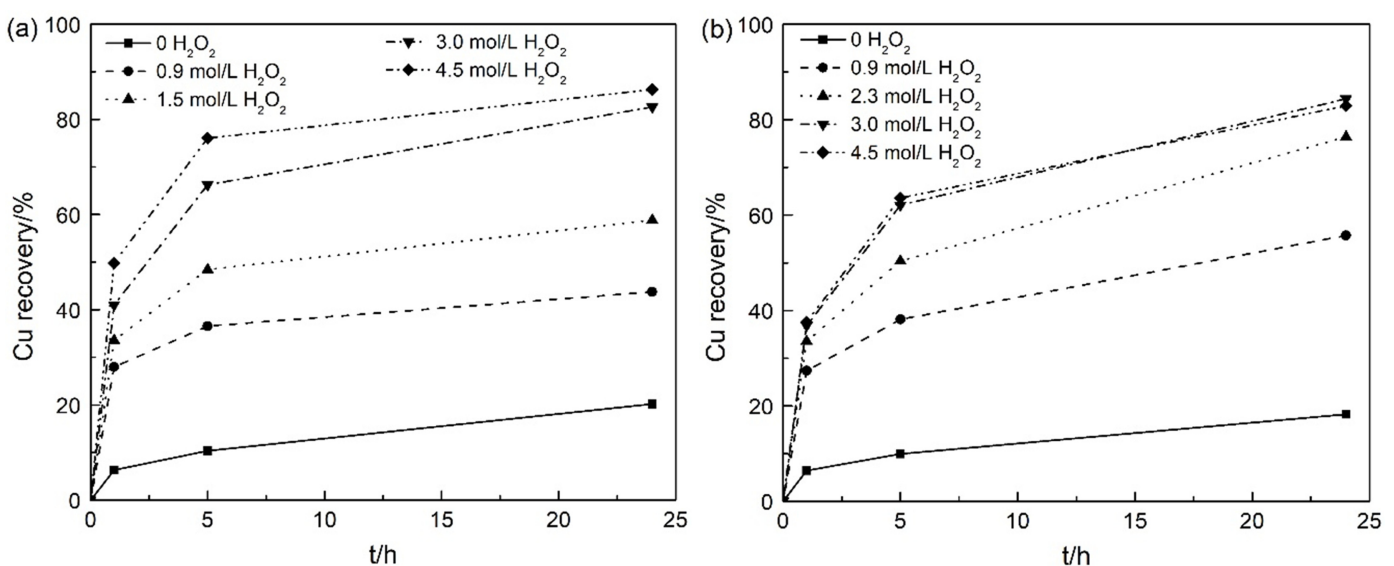

Fig. 5. Copper recovery of sample $\mathrm{B}$ under $\mathrm{H}_{2} \mathrm{O}_{2}$ leaching system with different lixiviants: $0.1 \mathrm{~mol} / \mathrm{L}$ sulfuric acid; (b) $0.3 \mathrm{~mol} / \mathrm{L}$ MSA

to sulfate and likely forms a passivation layer on chalcopyrite surface, resulting in the low overall copper recovery.

In leaching systems where $\mathrm{H}_{2} \mathrm{O}_{2}$ used as oxidant, as shown in Figure 5, a significant growth in the copper recovery was observed with increased $\mathrm{H}_{2} \mathrm{O}_{2}$ concentration. When $\mathrm{H}_{2} \mathrm{O}_{2}$ concentration exceeds $3.0 \mathrm{~mol} / \mathrm{L}$, over $80 \%$ extraction was achieved. This is due to the strong oxidizing ability of $\mathrm{H}_{2} \mathrm{O}_{2}$. Further increase $\mathrm{H}_{2} \mathrm{O}_{2}$ concentration from $3.0 \mathrm{~mol} / \mathrm{L}$ to 4.0 $\mathrm{mol} / \mathrm{L}$ didn't help a lot in the chalcopyrite dissolution because the strong decomposition of $\mathrm{H}_{2} \mathrm{O}_{2}$ at high concentration, especially under agitation condition with solids [17].

Abou-Yousef [18] reported that a stronger oxidant called "Caro's acid" (higher oxidizing potential than $\mathrm{H}_{2} \mathrm{O}_{2}$ ) is formed when $\mathrm{H}_{2} \mathrm{O}_{2}$ reacts with sulfuric acid, as illustrated in
Equation (4).

$$
\mathrm{H}_{2} \mathrm{O}_{2}+\mathrm{H}_{2} \mathrm{SO}_{4} \rightarrow \mathrm{H}_{2} \mathrm{SO}_{5}+\mathrm{H}_{2} \mathrm{O}
$$

Therefore, the dissolution kinetics were faster in sulfuric acid solution than MSA in the first hour due to the possibly formed stronger oxidant.

The dissolution of copper in the sulfuric acid/MSA and $\mathrm{H}_{2} \mathrm{O}_{2}$ can be shown as Equations (5) and (6) [19].

$2 \mathrm{CuFeS}_{2}+\mathrm{H}_{2} \mathrm{SO}_{4}+17 \mathrm{H}_{2} \mathrm{O}_{2}$

$\rightarrow 2 \mathrm{CuSO}_{4}+\mathrm{Fe}_{2}\left(\mathrm{SO}_{4}\right)_{3}+18 \mathrm{H}_{2} \mathrm{O}$

$2 \mathrm{CuFeS}_{2}+10 \mathrm{CH}_{3} \mathrm{SO}_{3} \mathrm{H}+17 \mathrm{H}_{2} \mathrm{O}_{2}$

$\rightarrow 2 \mathrm{Cu}\left(\mathrm{CH}_{3} \mathrm{SO}_{3}\right)_{2}+2 \mathrm{Fe}\left(\mathrm{CH}_{3} \mathrm{SO}_{3}\right)_{3}+4 \mathrm{H}_{2} \mathrm{SO}_{4}+18 \mathrm{H}_{2} \mathrm{O}(6)$

In $\mathrm{H}_{2} \mathrm{O}_{2}$ leaching system, chalcopyrite can be effectively 
oxidized and dissolved into the leaching solution. Moreover, to obtain good leaching results, relatively high $\mathrm{H}_{2} \mathrm{O}_{2}$ concentration should be maintained.

\section{CONCLUSION}

1. Approximately $60 \%$ copper extraction was achieved in sulfuric acid/MSA solution from sample A. The main dissolved minerals are copper oxides, and conichalcite is readily dissolved in acid solution. The effect of oxidants is not significant in the copper extraction.

2. Copper recovery of sample B increased with the presence of oxidants. The majority of chalcopyrite was oxidized at higher $\mathrm{H}_{2} \mathrm{O}_{2}$ concentration, and over $80 \%$ copper extraction was observed with $3.0 \mathrm{~mol} / \mathrm{L} \mathrm{H}_{2} \mathrm{O}_{2}$ and either lixiviants.

3. The copper coexisted with pyrite in sample A is almost insoluble and it was not oxidized by any oxidants in this test. For chalcopyrite in sample $\mathrm{B}, \mathrm{H}_{2} \mathrm{O}_{2}$ is a better oxidant than ferric ion.

\section{REFERENCES}

1. M. Brininstool and D. M. Flanagan, 2015 Minerals Yearbook Copper, p.20.8, U.S. Department of the Interior, U.S. Geological Survey, Virginia (2017).

2. I. Barton, J. Ahn, and J. Lee, Hydrometallurgy 176, 176 (2018).

3. H. Zhao, J. Wang, C. Yang, M. Hu, X. Gan, L. Tao, W. Qin, and G. Qiu, Hydrometallurgy 151, 141 (2015).

4. Á. Ruiz-Sánchez and G. T. Lapidus, Hydrometallurgy 169, 192 (2017).

5. J. B. Harlan, D. A. Harris, P. M. Mallette, J. W. Norby, J. C. Rota, and J. J. Sagar, Geology and mineralization of the Maggie Creek district, p. 115, NBMG Bulletin, Nevada
(2002).

6. E. M. Cameron, S. M. Hamilton, M. I. Leybourne, G. E. M. Hall, and M. B. Mcclenaghan, Geochemistry: Exploration, Environment, Analysis 4, 7 (2004).

7. L. Teal and A. Branham, Carlin-Type Gold Deposits Field Conference, p.257, Society of Economic Geologists, Nevada (1997).

8. M. S. Enders, Ph. D. Thesis, pp.171-176, The University of Arizona, Arizona (2000).

9. D. F. Briggs, History of the Copper Mountain (Morenci) Mining District, Greenlee County, Arizona, p.7, Arizona Geological Survey Contributed Report CR-16-C, Arizona (2016).

10. J.-A. Laffitte and B. Monguillon, US 8574370 B2, p.3, US. (2013).

11. L. N. Bengoa, P. Pary, M. S. Conconi, and W. A. Egli, Electrochim. Acta 256, 211 (2017).

12. T. Hidalgo, L. Kuhar, A. Beinlich, and A. Putnis, Miner. Eng. 125, 66 (2018).

13. Z. Wu, D. B. Dreisinger, H. Urch, and S. Fassbender, Hydrometallurgy 142, 23 (2014).

14. J. Ahn, I. F. Barton, D. Shin, and J. Lee, International Symposium on Materials Processing Fundamentals, 2018 Phoenix, United States, p.171, Springer, Cham, USA (2018).

15. E. M. Córdoba, J. A. Muñozb, M. L. Blázquez, F. González, and A. Ballester, Hydrometallurgy 93, 81 (2008).

16. C. Klauber, Int. J. Miner. Process. 86, 1 (2008).

17. E. Y. Yazıc1 and H. Deveci, Proceedings of The XIIth International Mineral Processing Symposium, CappadociaNevşehir, Turkey, p. 609. Hacettepe University, Turkey (2010).

18. H. Abou-Yousef, M. El-Sakhawy, and S. Kamel, Ind. Crop. Prod. 21, 337 (2005).

19. M. M. Antonijevic, Z. D. Jankovic, and M. D. Dimitrijevic, Hydrometallurgy 71, 329 (2004). 